Meta

Journal des traducteurs

Translators' Journal

\title{
Translational Shifts of Syntactic and Lexical Markers of Ideology: Reporting the Iraqi Conflict in Polish Reprint Press
}

\section{Ewa Gumul}

Volume 56, numéro 4, décembre 2011

URI : https://id.erudit.org/iderudit/1011251ar

DOI : https://doi.org/10.7202/1011251ar

Aller au sommaire du numéro

\section{Éditeur(s)}

Les Presses de l’Université de Montréal

ISSN

0026-0452 (imprimé)

1492-1421 (numérique)

Découvrir la revue

Citer cet article

Gumul, E. (2011). Translational Shifts of Syntactic and Lexical Markers of Ideology: Reporting the Iraqi Conflict in Polish Reprint Press. Meta, 56(4), 758-774. https://doi.org/10.7202/1011251ar

\section{Résumé de l'article}

Le présent article traite de la représentation de l'idéologie du texte de départ dans la traduction de la presse écrite, à l'aide d'une analyse des moyens lexicaux et grammaticaux. L'étude s'appuie en partie sur le cadre théorique de l'analyse critique du discours. Les mécanismes analysés sont la métaphore grammaticale, la transitivité, la modalité, le choix lexical, la prosodie sémantique et la cohésion. Le corpus de textes analysés a été fourni par l'hebdomadaire polonais Forum, qui republie des articles de presse internationaux de qualité traduits de l'anglais. Les articles choisis pour l'analyse concernent le conflit irakien de 2003 et ses conséquences. L'objectif de l'étude est d'étudier comment le choix des structures syntaxiques et lexicales peut influencer le contenu idéologique et le point de vue présentés dans le texte de départ. Étant donné le caractère spécifique des journaux qui publient des documents traduits, on a avancé l'hypothèse que les textes traduits devaient rendre fidèlement l'idéologie véhiculée par le texte source ou que l'intervention du traducteur devait être réduite au minimum. Cependant, les résultats mettent en évidence qu'une grande partie des textes traduits tombent dans la catégorie de la médiation partielle, ce qui change le point de vue communiqué au lectorat. 


\title{
Translational Shifts of Syntactic and Lexical Markers of Ideology: Reporting the Iraqi Conflict in Polish Reprint Press
}

\author{
EWA GUMUL \\ University of Silesia, Katowice, Poland \\ egumul@wp.pl
}

\section{RÉSUMÉ}

Le présent article traite de la représentation de l'idéologie du texte de départ dans la traduction de la presse écrite, à l'aide d'une analyse des moyens lexicaux et grammaticaux. L'étude s'appuie en partie sur le cadre théorique de l'analyse critique du discours. Les mécanismes analysés sont la métaphore grammaticale, la transitivité, la modalité, le choix lexical, la prosodie sémantique et la cohésion. Le corpus de textes analysés a été fourni par l'hebdomadaire polonais Forum, qui republie des articles de presse internationaux de qualité traduits de l'anglais. Les articles choisis pour l'analyse concernent le conflit irakien de 2003 et ses conséquences. L'objectif de l'étude est d'étudier comment le choix des structures syntaxiques et lexicales peut influencer le contenu idéologique et le point de vue présentés dans le texte de départ. Étant donné le caractère spécifique des journaux qui publient des documents traduits, on a avancé l'hypothèse que les textes traduits devaient rendre fidèlement l'idéologie véhiculée par le texte source ou que l'intervention du traducteur devait être réduite au minimum. Cependant, les résultats mettent en évidence qu'une grande partie des textes traduits tombent dans la catégorie de la médiation partielle, ce qui change le point de vue communiqué au lectorat.

\begin{abstract}
The present paper focuses on the notion of mediating source-text ideology in press translation, investigating lexico-grammatical resources. This study is partly set within the framework of Critical Discourse Analysis. The analysis focuses on such features as disambiguation or creation of grammatical metaphors (i.e., nominalisation and denominalisation), changes in transitivity patterns, modifications of the levels of modality, as well as shifts in lexical choice, semantic prosody and cohesion patterns. The source of the texts analysed in this paper is a Polish reprint magazine, Forum, publishing translated articles from a variety of English-language quality press titles. The articles selected for the analysis deal with the Iraqi conflict in 2003 and its aftermath. The aim of the study is to ascertain whether the lexical choice and the syntactic structures employed in the target texts engender changes in the ideological content of the source texts and the projected point of view. Given the nature of reprint press, a hypothesis has been formulated that the source-text ideology might remain unchanged in the process of translation or the translator's intervention is expected to be minimal. The results reveal, however, that a substantial proportion of the translated texts fall within the category of partial mediation, projecting an altered point of view to a target-text audience.
\end{abstract}

\section{MOTS-CLÉS/KEYWORDS}

idéologie, métaphore grammaticale, modalité, choix lexical, cohésion ideology, grammatical metaphor, modality, lexical choice, cohesion 


\section{Introduction}

The ideological potential of language has for almost three decades occupied a prominent place in the field of linguistic research. Various models have been developed to account for the interrelationship between language and ideology, a substantial number of them set within the framework of influential Critical Discourse Analysis (CDA) (e.g., Fairclough 1989; Fowler 1991; Simpson 1993).

This phenomenon also attracted considerable attention in the Translation Studies community, giving rise to, among others, a number of CDA-oriented studies in the field of translation (e.g., Hatim and Mason 1997; Puurtinen 2000, 2003; Schäffner 2003; Kemppanen 2004; Sidiropoulou 2004).

With the aid of the concepts and methods applied in previous research on the relationship of linguistic form and ideology in translation, the present study aims at investigating the translational shifts of lexical and syntactic markers of ideology, employing mostly the analytical toolkit of CDA.

Before venturing on the analysis proper, we shall begin with presenting the main concepts underlying the research and outlining the socio-political context, i.e., Polish engagement in the Iraqi conflict.

\section{Polish Involvement in the 2003 Iraq War}

Since the main aim of the paper is to analyse Polish translations of the articles concerning the Iraqi conflict in 2003, it is vital to present Polish attitudes towards the war itself and towards Polish involvement in the Operation Iraqi Freedom.

According to the report published in 2004 by the Warsaw-based independent and non-governmental Center for International Relations, Polish involvement in the 2003 Iraq war has been the most controversial undertaking of the Polish foreign policy in the last 15 years (Wągrowska 2004). ${ }^{1}$ These controversies are reflected in the wide spectrum of Polish attitudes towards this conflict. The official stance of the Polish government contrasted explicitly with that of the public opinion. Polish daily press, depending on the title, either supported or condemned the military invasion of Iraq.

On $17^{\text {th }}$ March 2003, Polish President Aleksander Kwaśniewski announced that Poland would send troops to Iraq to assist in enforcing the UN Security Council Resolution $1441 .^{2}$ The decision of the Polish government to send troops to Iraq meant Poland became a side in the conflict. All governmental sources present a uniform pro-war attitude. Bukowski and Ścigaj (2007) point to a variety of persuasive techniques adopted in the governmental documents. First of all, the war in Iraq was conveniently placed within a broader category of the war on terror. Moreover, frequent references to the elusive everyone and all, as well as to equally vague international community reinforce the impression that there is a uniform international agreement that the intervention in Iraq is essential (Bukowski and Ścigaj 2007: 18). It is also worth noting that the lexeme war is hardly ever used in governmental sources, and the lexemes invasion and intervention are never mentioned. US and coalition invasion of Iraq is euphemistically referred to as allied action, disarmament, Operation Iraqi Freedom, participation in the operation, and taking part in the coalition. The analysis of six Polish governmental documents from the year 2003 conducted by Bukowski and Ścigaj (2007) reveals also that in its announcements and 
speeches, the Polish government mostly focused on the imaginary vision of the world if the intervention had been abandoned rather than on the war itself. There was no attempt to answer those criticising the decision of the government. All critical voices were ignored as if there had been none.

Bukowski and Ścigaj (2007) also analysed four Polish major dailies (Gazeta Wyborcza, ${ }^{3}$ Rzeczpospolita, ${ }^{4}$ Nasz Dziennik ${ }^{5}$ and Trybuna $\left.{ }^{6}\right)$ in terms of their attitude towards the war itself and towards Polish involvement in it. Pisarek (2002) categorised these four newspapers in terms of their political profile on the basis of keywords (Pisarek uses the term słowa sztandarowe in Polish). According to him, Gazeta Wyborcza and Rzeczpospolita take a centrist-liberal stand, whereas Nasz Dziennik is believed to have a Catholic-national profile. The fourth daily - Trybuna displayed social-democratic leanings (it ceased publication in 2009).

The results obtained by Bukowski and Ścigaj (2007) show that Gazeta Wyborcza, considered one of the most influential and opinion-forming newspapers in Poland, displayed a strongly pro-American attitude. This was reflected in the use of marked lexemes and the fact that the war was described in terms of a political or media event without any references to moral, ethical or social issues. It is worth noting that although Gazeta Wyborcza appears to share the pro-war stance with the Polish government, the newspaper did not refer in any way to the official announcements of the Polish President, Prime Minister or any of the ministers. These were never discussed or quoted in the paper (Bukowski and Ścigaj 2007: 24-34). The attitude of another Polish daily - Rzeczpospolita has been interpreted as ambiguous by Bukowski and Ścigaj (2007: 34-44). On the one hand, in quantitative terms, the majority of opinions published in the paper tended to be in favour of the invasion. On the other hand, unlike in Gazeta Wyborcza, there were also some critical voices, although these were mostly the opinions of the journalists not employed at the paper. Similar ambiguity can be observed in Trybuna. This newspaper's stance cannot be perceived in terms of a simple binary opposition of "for" or "against." Trybuna officially supported the actions of the Polish government, publishing articles emphasising the legitimacy of the military intervention. Marek Barański, Trybuna's editor-in-chief, stated in the editorial that the invasion is to a large extent justified. There were, however, also some commentaries describing anti-war protests and pointing to potential negative consequences of the war (Bukowski and Ścigaj 2007: 44-52). The last analysed daily, Nasz Dziennik, strongly opposed military intervention in Iraq. Its radical anti-war attitude is reflected at the lexical level - the invasion is described as unfair, hostile, vile and cowardly. Instead of the frequent media lexemes like operation, intervention and mission, the war in Iraq is instead referred to as aggression or assault (Bukowski and Ścigaj 2007: 52-59).

According to the reports of the Polish Public Opinion Research Center (Centrum Badania Opinii Społecznej, CBOS) ${ }^{7}$ published between January 2003 and May 2004 (CBOS January 2003, November 2003, April 2004; Grudniewicz 2003a, 2003b, 2004), ${ }^{8}$ Polish public opinion was strongly against the invasion in Iraq and especially the involvement of the Polish troops. The January issue of CBOS's bulletin Polish Public Opinion reports that $51 \%$ of the respondents declared diminishing support for the intervention in Iraq. In a survey conducted in March 2003 the number increased significantly $-61 \%$ of the respondents stated there should be no military intervention in Iraq. More than half (66\%) of the Polish population opposed participation by its 
troops in Iraq. The author (Grudniewicz 2003a) summarises the report as clearly indicating lack of support for the military invasion of Iraq. Similar results were obtained in mid-March by the Polish public opinion service TNS OBOP ${ }^{9}-69 \%$ disapproved of the Polish government's decision to send troops to Iraq (Wągrowska 2004). The poll conducted in June 2003 confirmed that many Poles feared the presence of the Polish soldiers in Iraq would result in terrorist attacks on Poland (Grudniewicz 2003b). In October 2003 the level of support was the lowest since the first Polish military contingent left for Iraq. As many as two-thirds of Poles did not approve of Poland's participation in the operation (CBOS November 2003). Another survey by CBOS from April 2004 showed that the number of the respondents who believed that Poland would become a target of terrorist attacks due to the presence of the Polish troops in Iraq increased almost twofold compared with December 2003. The number of Poles who associated the mission in Iraq with possible terrorist attacks had grown by 16 percentage points to $87 \%$ (CBOS April 2004). The report published in May 2004 notes that as many as $74 \%$ of the Polish population declared lack of support for the mission in Iraq. This increase was probably due to the death of two Polish soldiers and two journalists in Iraq, as well as frequent media reports about Human Rights abuses of the Iraqi POWs by the American army (Grudniewicz 2004). The fact that most of the Polish population was strongly against the invasion of Iraq and the involvement of the Polish troops in the mission is also emphasised in the report published in December 2004 by the non-governmental Center for International Relations (Wągrowska 2004).

\section{The Notion of Ideology}

Ideology is a concept which is notoriously difficult to define. Expounded and analysed in terms of a political doctrine or a philosophical stance, frequently used in contexts in which it is imbued with negative connotations denoting overt manipulation and deception, the term ideology is also assigned a more neutral meaning. This understanding of the concept of ideology is reflected in Simpson's (1993) definition of this notion, whereby ideology derives from "the taken-for-granted assumptions, beliefs and value systems which are shared collectively by social groups" (Simpson 1993: 5). Mason's (1994) understanding of the term also goes beyond the frequently used sense of political doctrine and instead focuses on a more neutral "set of beliefs and values which inform an individual's or institution's view of the world and assist their interpretation of events, facts, etc." (Mason 1994: 25).

Such views on the term ideology, adopted for the purpose of CDA-oriented research and much favoured by other translation researchers, form the basis of Puurtinen's (2003) understanding of this notion. In her research into linguistic realisations of ideology, Puurtinen uses ideology as the umbrella term for three phenomena. In her view, "ideology refers [...] to the ways in which linguistic choices made by the writer or translator of a text, first, create a particular perspective on the events portrayed, second, may reflect the writer's opinion and attitudes, and third, may be used to influence readers' opinions" (Puurtinen 2003: 53). This definition has been adopted in the present paper to form the basis for the analysis of linguistic markers of ideology in press translation. ${ }^{10}$ 


\section{Linguistic Markers of Ideology}

The discourse features claimed by numerous researchers to serve as vehicles of ideological meaning are: grammatical metaphors, transitivity, modality, lexical choice, and cohesion.

Grammatical metaphor, the concept propounded by Halliday (1985/1994) within his framework of Systemic Functional Grammar, is perceived as an alternative lexicogrammatical realization of a semantic choice. The situation described in a sentence might be realized in two different ways on the level of syntax: by a semantically congruent construction, when semantic functions fulfil primary syntactic roles, and by a semantically non-congruent construction, i.e., grammatical metaphors, when semantic functions play secondary syntactic roles (Ravelli 1988). It is worth noting that metaphorical constructions and their congruent equivalents should never be perceived in terms of a mere variance in syntactic form, since different structuralisations might be referring to the same entities but do not communicate the same (Jędrzejko 1993). Variation in a lexicogrammatical realization is generally associated with differences in interpretation and different discourse and stylistic effects (Sušinskiene 2004).

According to Halliday (1985/1994), the most powerful resource for creating grammatical metaphor is nominalisation, i.e., substituting verbal constructions with nominal ones. By means of such transformation, processes and properties (congruently worded as verbs and adjectives respectively), are reworded metaphorically as nouns, which makes the resulting construction more abstract, impersonal and increases its lexical density. The manipulative potential of nominal constructions is also frequently underscored in other works (e.g., Fairclough 1989; Fowler 1991; Hodge and Kress 1993). Obviously, the reverse transformation, i.e., substituting nominal constructions with verbal ones (denominalisation), which is an instance of disambiguating grammatical metaphors, also carries a potential of ideological manipulation (see Gumul 2006b; Gumul and Łyda 2010). It makes process participants visible in the sentence and reduces the experiential distance, i.e., distance between text and the reality which it portrays (Puurtinen 2003).

Ideological import of a text might also be reflected in the transitivity patterns. The understanding of the concept of transitivity adopted in the studies on the linguistic aspects of ideology (e.g., Fowler 1991; Simpson 1993; Halmari 1999) is much wider than that employed in traditional grammars. It generally refers to how meaning is represented in the clause and shows how speakers encode in language their mental picture of reality and how they account for their experience of the world around them. In Simpson's (1993) transitivity model there are four major categories of processes: material, verbalisation, mental and relational processes.

An important part of the transitivity system of language is passivisation. This syntactic transformation is claimed to have a strong effect on the way we perceive events and actions (e.g., Fairclough 1989; Fowler 1991; Halmari 1999; Awdiejew 2004). Passive sentences can be an effective neutralising (or mystifying) means of representing actions, processes and participants in such a way that causal relations and responsibility for actions become obscure (Puurtinen 2000).

Another discourse feature which serves as a vehicle of ideological meaning is modality. Following Fowler (1991), the notion of modality is understood here simply as comment or attitude, which is by definition ascribable to the source of the text, 
and explicit or implicit in the linguistic stance taken by the writer/translator (Fowler 1991). According to Simpson (1993), it is the epistemic modality which is possibly the most important regarding the analysis of point of view. Epistemic modality is concerned with the writer's confidence or lack of confidence in the truth of a proposition expressed (Simpson 1993).

The writer's or translator's point of view might also be reflected in the lexical choice. It is often the strength of powerful connotations attached to seemingly equivalent lexical items which gives the source text and the target text different shades of meaning changing the ideology conveyed. A target text might also create an impression of different point of view if the semantic prosody is altered, which is "a consistent aura of meaning with which a form is imbued by its collocates" (Kemppanen 2004: 93).

Cohesion is another discoursal feature which is believed to have the power to modify the ideology of the text. Hatim and Mason (1997) underline the manipulative potential of lexical cohesion providing abundant exemplification of, for example, varying lexicalisation, which in Halliday and Hasan's (1976) terms would mean substituting reiteration in the form of identical/partial repetition with reiteration in the form of paraphrase. Another type of cohesion referred to in the studies on ideology in language is explicitation of clausal relations, which takes the form of adding connectives (e.g., Sidiropoulou 2004).

\section{Research Design}

As all these features may potentially lead to distortions of the ideology projected by the source text, the aim of the present paper is thus to ascertain whether the lexical choice and the syntactic structures employed in the target texts engender changes in the ideological content of the source texts. The purpose of the analysis is not only to identify these types of syntactic and lexical modifications, but also to establish whether these operations are performed by translators in a systematic and consistent manner, resulting in the manipulation of the source-text ideology.

This study is partly set within the framework of Critical Discourse Analysis (CDA), and thus relies heavily on the models developed and employed by Halliday (1985/1994), Fairclough (1989), Fowler (1991), and Simpson (1993). The analysis is based on Hatim and Mason's (1997) model of 3 degrees of translator's mediation: minimal, partial and maximal mediation.

The corpus of the study consists of 22 feature articles which appeared in the Financial Times, the International Herald Tribune, the Los Angeles Times, The Atlantic, The Guardian, The Independent, The Spectator, The Times, The Washington Post and Time (see Appendix). The articles selected for the analysis deal with the Iraqi conflict in 2003 and its aftermath. The analysed target texts are the translations of these articles published in the Polish reprint magazine Forum ${ }^{11}$ between January 2003 and May 2004, which altogether constitute a corpus of approximately 32,000 words. Forum published 22 articles concerning the Iraqi conflict and all of these articles were analysed in the present research project.

Forum is a Polish reprint magazine that publishes only translations of the world press articles. This weekly magazine was established in 1965 and has a circulation of 54,000 . Their official statement regarding the paper's editorial policy reads: The editorial 
staff reserves the right to change the titles and leads of translated articles and to shorten them as long as the changes do not distort the meaning of the original. The magazine's own texts, commentaries, and editorial annotations are signed separately. According to the media report by Brief.pl, ${ }^{12}$ the Last Issue Readership (COW) indicator is $0.4 \%(118,958)$ and Season Cycle Readership (CCS) is $0.8 \%(244,248)$. It is aimed at educated readers. Readership surveys indicate that Forum has a fairly high ratio of young readers (29\% are below the age of 24$), 29 \%$ are students and $39 \%$ are city dwellers. The magazine claims to have no ideological stance, which is also confirmed by Brief.pl media report.

Since the main function of the reprint magazine seems to be to acquaint the Polish readership with the opinions expressed by journalists in foreign press, the initial hypothesis holds that the vast majority of the articles might either mediate the source-text ideology unchanged or fall within the category of minimal mediation. We are referring here to the term coined by Hatim and Mason (1997) to refer to those target texts in which the scale of introduced translational shifts is relatively small. The other degrees of mediation in this classification are partial and maximal mediation, the latter describing a situation when translator's mediation "issues from and constructs a different ideology" (Hatim and Mason 1997: 158) and when significant discoursal shifts occur between source- and target-language versions throughout the text. Thus, different degrees of translator's mediation can be said to reflect "the extent to which translators intervene in the transfer process, feeding their own knowledge and beliefs into their processing of a text" (Hatim and Mason 1997: 147).

While discussing Hatim and Mason's (1997) model of three degrees of translator's mediation, it seems essential to mention the potential problems with its application in empirical quantitative research. The major shortcoming of the model is the lack of clear-cut quantifiable boundaries between individual categories. Thus, the author of the present paper made an attempt to adjust the model in order to facilitate quantitative analysis. An assumption was made that minimal mediation should involve no more than 3 shifts per each 1000 words of the target text, partial mediation - between 4 and 7 shifts, and maximal - over 7, on condition that the identified modifications form a consistent pattern in terms of the point of view conveyed. Obviously, such division is clearly an oversimplification, as it is not only the number of translational shifts that adds to the final effect of the target text, but also the force of the impact individual modifications have on the target audience. Nevertheless, it is hoped that establishing such borderlines might facilitate to a certain extent the quantitative analysis. It should be emphasized, however, that it is not the only criterion applied in the present research project.

Before presenting the results of the research, it seems essential to mention the major assumptions underlying analysis in the present study. First of all, it was borne in mind that no marker of ideology is inherently ideologically loaded. It is frequently underscored in works dealing with ideological aspects of language that "none of the linguistic forms is always an indicator of ideology in a text and should not automatically be interpreted as such" (Puurtinen 2000: 179). A particular linguistic form should never be automatically interpreted as an expression of a particular ideological meaning. Firstly, there might as well be a host of other reasons underlying translators' surface choices, and secondly, these surface choices might not affect the ideological perspective of the text. 
Therefore, although the analysis was performed on the level of texture, i.e., dealing with the micro-level manifestations of ideology, the judgement concerning the potential ideological significance of a given item was always made with reference to the text as a whole as well as the extralinguistic reality (i.e., the socio-political context).

\section{Results}

The results fail to support fully the initial hypothesis, as only 5 of the analysed articles mediate source text ideology unchanged and as many as 8 might be considered as falling into the category of partial mediation:

TABLE 1

\section{Degrees of translators' mediation}

\begin{tabular}{|l|c|}
\hline Degree & Number of articles \\
\hline Maximal mediation & 0 \\
\hline Partial mediation & 8 \\
\hline Minimal mediation & 9 \\
\hline Ideology unchanged & 5 \\
\hline
\end{tabular}

In fact, the category labelled as "ideology unchanged" also subsumes those target texts in which potentially ideologically loaded constructions or lexical items could be found, but the pattern was not consistent, and therefore they could not be interpreted as projecting an altered ideological point of view. In 9 cases the translator's involvement can be described in terms of minimal mediation, and none of the target texts appears to be promoting ideology that is fundamentally at variance with that of the source text.

The most common shifts (mentioned here in the order of frequency of occurrence) include alterations in: lexical choice, cohesion pattern, transitivity pattern, and the level of modality. Table 2 presents the results of the analysis - the total number of shifts occurring in each article and the dominant shifts:

TABLE 2

Most common shifts occurring in the analysed articles

\begin{tabular}{|c|c|c|c|}
\hline $\begin{array}{l}\text { Article } \\
\text { Number }\end{array}$ & $\begin{array}{l}\text { Author and } \\
\text { publication date }\end{array}$ & $\begin{array}{l}\text { Number } \\
\text { of shifts }\end{array}$ & Dominant shifts \\
\hline 1 & Anderson, 8 May 2004 & 3 & $\begin{array}{l}\text { lexical choice, alteration in transitivity pattern, } \\
\text { shift in the level of modality }\end{array}$ \\
\hline 2 & Beattle et al, 22 March 2003 & 5 & lexical choice, modification of cohesive pattern \\
\hline 3 & Clover, 5 July 2003 & 6 & lexical choice, alteration in transitivity pattern \\
\hline 4 & Cornwell, 8 March 2003 & 6 & $\begin{array}{l}\text { nominalisation, passivisation, modification of } \\
\text { cohesive pattern (explicitation of clausal } \\
\text { relation) }\end{array}$ \\
\hline 5 & Fisk, 27 January 2003 & 6 & $\begin{array}{l}\text { shift in the level of modality, alteration in } \\
\text { transitivity pattern }\end{array}$ \\
\hline 6 & Fisk, 26 March 2003 & 2 & lexical choice, modification of cohesive pattern \\
\hline 7 & Ghattas, 31 July 2003 & 3 & $\begin{array}{l}\text { lexical choice, alteration in transitivity pattern, } \\
\text { shift in the level of modality }\end{array}$ \\
\hline 8 & Hari, 3 December 2002 & - & ideology unchanged \\
\hline
\end{tabular}




\begin{tabular}{|c|l|c|l|}
\hline 9 & Kaplan, 9 November 2002 & 6 & lexical choice \\
\hline 10 & Kellner, 19 July 2003 & 5 & $\begin{array}{l}\text { lexical choice, modification of cohesive pattern, } \\
\text { shift in the level of modality }\end{array}$ \\
\hline 11 & King, 3 May 2003 & - & ideology unchanged \\
\hline 12 & Kruger, 15 March 2003 & - & ideology unchanged \\
\hline 13 & Lawson, 19 April 2003 & 2 & lexical choice, modification of cohesive pattern \\
\hline 14 & Macaskill, 28 October 2003 & - & ideology unchanged \\
\hline 15 & Nye, 19 May 2004 & 3 & $\begin{array}{l}\text { lexical choice, alteration in transitivity pattern, } \\
\text { shift in the level of modality }\end{array}$ \\
\hline 16 & Sachs, 10 September 2003 & 7 & $\begin{array}{l}\text { lexical choice, modification of cohesive pattern, } \\
\text { disambiguating grammatical metaphor }\end{array}$ \\
\hline 17 & Seaton, 19 February 2003 & - & ideology unchanged \\
\hline 18 & Waller, 27 January 2003 & 3 & lexical choice \\
\hline 19 & Weiss, 18 April 2003 & 2 & lexical choice, modification of cohesive pattern \\
\hline 20 & Whitworth, 23 January 2003 & 7 & lexical choice, shift in the level of modality \\
\hline 21 & Wise, 27 January 2003 & 3 & lexical choice, alteration in transitivity pattern \\
\hline 22 & $\begin{array}{l}\text { Wright and Williams, } \\
\text { 13 November 2003 }\end{array}$ & 2 & $\begin{array}{l}\text { modification of cohesive pattern (explicitation } \\
\text { of clausal relation) }\end{array}$ \\
\hline
\end{tabular}

Presenting all the examples illustrating individual shifts is clearly beyond the scope of the present paper. Thus only a selection of the most representative instances of translational shifts of syntactic and lexical markers of ideology will be presented below. Each of the selected articles is represented by two or more examples in order to demonstrate the patterns of shifts within particular texts.

The first example illustrates changes in the lexical selection. The neutral item continued is rendered as prolonged (przedłużająca się) in the TT, giving it a distinctly negative connotation. It is further emphasised by the addition of a conclusive temporal marker of cohesion finally, which makes the acceptance seem more delayed in time and even less probable:

(1) Text 16: Mr Bush and his team believe the situation will stabilise step by step. They express confidence that anti-terror raids will vanquish the enemy; that improved public services will win the hearts and minds of the population; and that the continued US military presence will become an accepted fact on the ground.

(Sachs 10 September 2003, Financial Times)

Administracja Busha zakłada, że sytuacja w Iraku będzie się stopniowo stabilizować. Jej zdaniem operacje antyterrorystyczne wyeliminują wroga, poprawa warunków życia zjedna serca i umysły irackiej ludności; a przedłużająca się obecność amerykańskich żołnierzy w tym kraju zostanie w końcu zaakceptowana.

(Sachs 15 September 2003, Forum)

[Bush administration assumes that the situation in Iraq will gradually stabilise. According to them, the antiterrorist operations will eliminate the enemy, the improvement of living conditions will win the hearts and minds of the Iraqi population; and the prolonged presence of the American soldiers in this country will finally be accepted.]

(Back translation by the author)

There are some more shifts encountered in the same article, which form a consistent pattern with those we have just discussed: 
(2) Text 16: Mr Bush has committed nearly 1 per cent of US gross national product for the coming year, on top of about 0.6 per cent of GNP during the past 12 months.

(Sachs 10 September 2003, Financial Times)

Na przyszły rok Bush rozdysponował za jednym zamachem kwotę równą blisko jednemu procentowi amerykańskiego produktu krajowego brutto, a przecież ciągu ostatnich 12 miesięcy wydał już równowartość 0,6 proc. PKB.

(Sachs 15 September 2003, Forum)

[For the coming year Mr Bush has committed with one swift move nearly 1 per cent of US gross national product. After all, during the past 12 months, he already spent the equivalent of about 0.6 per cent of GNP.]

(Back translation by the author)

The translator opts for a more explicit and emphatic form to mark additive relation (after all) and substitutes nominal structure with a verbal one (he already spent), a clear case of disambiguating a grammatical metaphor. Such operation brings to the surface the agenthood, pointing directly to the actor of the process. Addition of already appears to provide further emphasis. All these alterations seem to be adding to the condemnation of American policy in Iraq. The point of view presented in the target text appears to be even more critical of it than that of the source text.

Some of the other features encountered in this particular article, consistent with other, previously discussed, shifts, include, for instance, the addition of intra-textual headings: Help is superfluous or Dead end to refer to US occupation of Iraq. Even though the expression dead end is employed in the body of the source text, its recurrent use in the target-language version and assigning it a status of a heading, naturally standing out from the text (Reah 1998), further emphasises the problematic character of American endeavours.

Another feature of this article that merits attention is the eight-node lexical cohesion chain of the word occupation. The reiteration pattern is not fully maintained in the target text, as there are significant shifts in four of the nodes (b, c, e and $\mathrm{f}$ ):

(3) Text 16: (a) military occupation

(b) US occupation

(c) America's occupation

(d) occupation strategy

(e) US occupation

(f) US occupation

(g) occupation

(h) occupation costs

$\begin{array}{ll}\begin{array}{l}\text { okupacja } \\ \text { okupacja Iraku }\end{array} & \text { [occupation] } \\ \begin{array}{l}\text { Amerykanie } \\ \text { strategia okupacyjna } \\ \text { okupacja Iraku } \\ \text { (omitted fragment) }\end{array} & \text { [Americans] } \\ \text { okupacja } & \text { [occupation strategy] } \\ \text { koszty okupacji } & \text { [occupation] } \\ \text { [occupation costs] }\end{array}$

(Sachs 10 September 2003, Financial Times;

Sachs 15 September 2003, Forum; Back translation by the author)

In nodes (b) and (e), there is a shift of focus to another element of the script occupATION - from the aggressors to the victims. Additionally, in node (c), there is clearly a metonymic relation between source-text item America's occupation and its targettext equivalent Americans. Due to this shift, it is not the impersonal phenomenon of occupation that is to blame, but the actual people - the Americans. Shifts within this particular reiteration chain may also have a more global impact on the target-text reception, as reiteration or recurrence, to use de Beaugrande and Dressler's (1981) term, is a textual feature "used to assert and reaffirm one's viewpoint" (de Beaugrande 
and Dressler 1981: 55). Thus, any modification of a cohesive chain of this type is bound to result in changes of the point of view conveyed.

The following two extracts from another article illustrate, among others, a marked tendency of altering the level of modality:

(4) Text 20: A tiny gulf state that forged close links with America to protect itself from predatory Arab neighbours will be the command centre for US forces during any war on Iraq.

(Whitworth 23 January 2003, The Times)

To nie fatamorgana: Katar, mały emirat nad Zatoką Perską, jest najbardziej prozachodnim państwem arabskim i ma świetne stosunki z USA. Możliwe, że właśnie stąd ruszy amerykańskie uderzenie na Bagdad.

(Whitworth 3 February 2003, Forum)

[It is not a mirage: Qatar, a small emirate on the Persian Gulf, is the most proWestern Arab country and has excellent relations with the USA. It is possible that it will from there that the American strike against Baghdad will be launched.]

(Back translation by the author)

In the above example, a definitive will is rendered as it is possible, which results in a drastic change in the level of certainty. When we analyse this particular example in the context of other shifts introduced to the target text, it becomes obvious that it might attest to the translator's lack of confidence in the truth of the proposition expressed or alternatively, to his or her intention to create such an impression on the target audience. The impression of an undermined importance of Qatar is reinforced by other shifts: addition of the whole proposition it is not a mirage, implying the implausibility of the whole project, and omission of the details regarding the reasons why Qatar forged close links with America (to protect itself from predatory Arab neighbours). Substituting the latter information with the adjective pro-Western strengthens the impression of an altered point of view projected by the target text.

The case is further illustrated by another extract from the same article, in which the choice of the tentative form sometimes, implying occasional commitment of the state, to substitute a definitive and unconditional even if it means, marks the shifts in the level of modality. The highlighted lexical selection seems to communicate a message that is consistent with the other lexical and syntactic shifts that can be found in this text. Highly appreciative item remarkable is rendered as merely efficient - a form implying adequacy or acceptability rather than esteem:

(5) Text 20: Qatar has a remarkable welfare state; citizens do not pay income tax but still receive free education and healthcare, even if it means being flown to Britain or the US for an operation.

(Whitworth 23 January 2003, The Times)

Katar to przykład sprawnego państwa opiekuńczego. Obywatele nie płacą podatku dochodowego, a mimo to mają darmową oświatę i opiekę zdrowotną (bywa, że państwo finansuje operacje w zachodnich szpitalach).

(Whitworth 3 February 2003, Forum)

[Qatar is an example of an efficient welfare state. Citizens do not pay income tax but still have free education and healthcare (sometimes the state finances operation in Western hospitals).]

(Back translation by the author) 
The article in question abounds in other shifts in modality, forming a consistent pattern with those discussed above.

An extract from another article illustrates two more types of translational shifts:

(6) Text 3: As Adnan Pachachi, an Iraqi politician, puts it: "At least we know who is responsible, where to go and who is the guy making the decisions here."

(Clover 5 July 2003, Financial Times)

Jak określa to iracki polityk Adnan Paczaczi: „Przynajmniej wiemy, kto ponosi teraz odpowiedzialność i kto podejmuje tu decyzje.”

(Clover 14 July 2003, Forum)

[As an Iraqi politician, Adnan Pachachi, puts it: "At least we know who bears the responsibility [...] and who makes the decisions."]

(Back translation by the author)

In the first place we can see the consequence of a lexical choice: juxtaposing the noun responsibility with its collocate bears changes the semantic prosody of the utterance, loading it with a distinctly negative connotation and implying blame. This impression is strengthened by the omission of the phrase where to go in the target text.

The following example coming from the same source is an instance of alteration in the transitivity pattern - a shift from material to relational process:

(7) Text 3: Many Iraqis, and western aid workers in Baghdad, blame his administration for letting day-to-day problems slide out of control.

(Clover 5 July 2003, Financial Times)

Liczni Irakijczycy i pracownicy zachodnich organizacji humanitarnych obwiniają jego administrację o niezdolność do rozwiązywania problemów dnia codziennego.

(Clover 14 July 2003, Forum)

Many Iraqis, and western aid workers blame his administration for being incapable of solving day-to-day problems.

(Back translation by the author)

This results in a clear change in the projected point of view: source-text letting problems slide out of control suggests negligence, giving an impression of an involuntary action in a way, whereas the target-text solution - being incapable to solve problems points to incompetence.

The following extract from another article provides further examples of similar translational shifts:

(8) Text 10: It looks as if, for a significant minority of the people of Baghdad, the jury is still out on whether the war was worthwhile. If most of these people can be won over, then - and only then - will it be possible for the Americans to claim that a large majority of the people of Iraq's capital are on their side.

What must the Americans (and the British, for that matter) do? One urgent need is to convince Iraqis that their case was just.

(Kellner 19 July 2003, Spectator)

Można odnieść wrażenie, że spora część mieszkańców miasta nadal nie rozstrzygnęła, czy warto było toczyć tę wojnę.

Amerykanie i Brytyjczycy muszą szybko przekonać Irakijczyków o słuszności swej sprawy. 
It looks as if a significant number of the inhabitants of the city still have not decided whether it was worth fighting this war.

The Americans and the British must quickly convince Iraqis about the rightness of their case.

(Back translation by the author)

This particular fragment shows how the picture of the American/British and Iraqi attitudes towards the war is altered in the process of translation. Rendering a significant minority as a significant number clearly changes the expectations of the readers as to the actual numbers of people behind this general phrase. This change in proportions is strengthened by the omission of the conditional sentence that follows immediately. This rather emphatic sentence seems to suggest a certain degree of uncertainty and caution, possibly even a desire not to appear over-confident. That is at least how the author of the article attempts to present the American/British position. The rhetoric question, which takes the form of a matter-of-fact statement in the target text, appears to have the same function. Thus, as a result of such modifications, the reader of the target text receives a false message that implies more doubts on the part of the Iraqis and more certitude on the part of the Americans and the British than is suggested in the source text. It is also interesting to note that whereas in the source text, by means of a graphic convention, American and British involvement is not equally prominent (the Americans (and the British, for that matter)), in the target text both nations are put on an equal footing, which implies the same degree of involvement of both subjects (the Americans and the British).

Another extract from the same article illustrates shifts that appear to be consistent with those discussed above:

(9) Text 10: This bleak mood even extends to many of those who say we were right to go to war. Just half say that life is now better, while one in three of the pro-war camp say life is now worse.

(Kellner 19 July 2003, Spectator)

Ten ponury nastrój udziela się również wielu osobom, które twierdzą skądinąd, że wojna była słuszna. Tylko połowa z nich uważa, że teraz życie jest lepsze, a jedna trzecia - że gorsze.

(Kellner 4 August 2003, Forum)

This bleak mood extends also to many people who otherwise claim that it was right to go to the war. Only half of them think that life is now better, while onethird thinks it is worse.

(Back translation by the author)

The shift that has some influence on the point of view conveyed in the text is the alteration of the cohesion pattern: emphatic even is substituted with additive also, making the proposition appear more natural and predictable. This impression is reinforced by a shift in modality - addition of otherwise (skądinąd), which expresses less confidence in the truth of this proposition. Moreover, there is another translational shift that forms a consistent pattern: whereas the source text reiterates the information (those who say we were right to go to war - the pro-war camp), the target text omits the second part of this cohesive tie, weakening the impact of the proposition. 


\section{Conclusions}

Although the exemplification presented here is far from exhaustive, the results of the present study reveal that a substantial proportion of the analysed target texts communicate an altered point of view to the Polish readership. Despite the fact that none of the text projects a fundamentally different ideology, the pattern of the translational shifts is sufficiently clear to legitimize a conclusion of an altered viewpoint.

As illustrated by the examples extracted from the analysed texts, the articles displaying a consistent pattern of ideologically-loaded translational shifts tend to reflect the anti-war attitude of the Polish public opinion rather than the government's pro-war stance. In many cases the analysed translations are more critical of the invasion of Iraq than the source texts. It is worth noting that none of the target-text presents military intervention in Iraq in a more favourable light.

Such changes might be seen as reflecting translators' personal opinions and attitudes. Obviously, it would be tempting to assume that they are fully conscious choices of the target text producer. However, given the nature of the analysed material (press translations performed by anonymous translators) and the research design (purely product-oriented analysis), it is hard to determine whether a given shift is a result of a deliberate translator strategy. In fact, as underscored by various researchers, such modifications, even if reflecting a personal point of view, are not necessarily conscious. One cannot also rule out the possibility that some of these shifts might be attributable to lack of expertise on the part of a translator, although the shifts that were incidental were not taken into account and the criterion of a consistent pattern was of a paramount importance. Finally, it is worth mentioning that since a substantial proportion of discussed translational shifts fall either within the category of explicitation or implicitation (see Gumul 2006a, 2008, 2010), both of which are widely recognized as translation universals, some of these modifications might simply be seen as a by-product of language mediation.

Notwithstanding the exact reasons for such translational decisions and the resulting shifts, the analysed material proves that lexis and syntax are powerful tools in the hands of translators and that seemingly innocent and neutral operations involved in interlingual transfer might have serious ideological consequences.

\section{NOTES}

1. WąGrowska, Maria (2004): Udział Polski w interwencji zbrojnej i misji stabilizacyjnej w Iraku. Centrum Stosunków Międzynarodowych. Raporty i Analizy 12/04. Visited on 15 February 2006, <http://www.leidykla.vu.lt/inetleid/kalbot/kalbot3/54_3/straipsniai/str10.pdf>.

2. The official website of the President of the Republic of Poland. Visited on 5 May 2009, <http://www. prezydent.pl>.

3. Gazeta Wyborcza. Visited on 10 December 2010, <http://wyborcza.pl>.

4. Rzeczpospolita. Visited on 10 December 2010, <http://www.rp.pl>.

5. Nasz Dziennik. Visited on 10 December 2010, <http://www.naszdziennik.pl>.

6. Trybuna. The paper ceased to exist on 7 December 2009.

7. Centrum Badania Opinii Społecznej/Polish Public Opinion Research Center (CBOS). Visited on 20 December 2010, <http://www.cbos.pl>.

8. CBOS (January 2003): Diminishing Support for the Intervention in Iraq. Polish Public Opinion, 1. Visited on 29 December 2010, <http://www.cbos.pl/PL/publikacje/public_opinion/2003/01_2003. $\mathrm{pdf}>$.

CBOS (November 2003): Poles about the Stabilisation Mission in Iraq. Polish Public Opinion, 1. Visited on 29 December 2010, <http://www.cbos.pl/PL/publikacje/public_opinion/2003/11_2003.pdf>. 
CBOS (April 2004): Increased Fear of Terrorism. Polish Public Opinion, 2-3. Visited on 29 December 2010, <http://www.cbos.pl/PL/publikacje/public_opinion/2004/04_2004.pdf>.

GrudniewiCz, Anna (2003a): Wzrost nastrojów antywojennych. Komunikat z badań. CBOS, BS/51. Visited on 31 December 2010, <http://www.cbos.pl/SPISKOM.POL/2003/K_051_03.PDF>.

GrudniewiCz, Anna (2003b): Wzrost poczucia zagrożenia terroryzmem w związku z obecnością polskich żołnierzy w Iraku. Komunikat z badań. CBOS, BS/106. Visited on 31 December 2010, <http://www.cbos.pl/SPISKOM.POL/2003/K_106_03.PDF>.

GrudniewiCz, Anna (2004): Spadek poparcia dla obecności polskich żołnierzy w Iraku. Komunikat z badań. CBOS, BS/86. Visited on 31 December 2010, <http://www.cbos.pl/SPISKOM. POL/2004/K_086_04.PDF>.

9. TNS OBOP (Ośrodek Badania Opinii Publicznej) - Polish public opinion research agency. Visited on 29 December 2010, <http://www.obop.pl/home-en>.

10. The term press translation has been adopted in the present study, rather than news translation or more generally media translation, to denote translation of feature articles for reprint press.

11. Forum. Visited on 25 March 2009, <http://www.tygodnikforum.pl>.

12. Brief.pl is a Polish marketing and sales magazine. Visited on 5 May 2009, <http://www.brief.pl>.

\section{REFERENCES}

Awdiejew, Aleksy (2004): Systemowe środki perswazji. In: Piotr Krzyżanowski and Paweł NowaK, eds. Manipulacja w języku. Lublin: Wydawnictwo UMCS, 71-80.

De Beaugrande, Robert-Alain and Dressler, Wolfgang (1981): Introduction to Text Linguistics. London/New York: Longman.

Bukowski, Michał and ŚcigaJ, Paweł (2007): Prasa codzienna wobec udziału polskich żołnierzy w operacji "Iracka Wolność." In: Witold Dzielski and Wojciech Michniк, eds. Irak. Dylematy amerykańskiej interwencji. Kraków: Księgarnia Akademicka, 11-62.

FairClough, Norman (1989): Language and Power. London/New York: Longman.

Fowler, Roger (1991): Language in the News. Discourse and Ideology in the Press. London/ New York: Routledge.

Gumul, Ewa (2006a): Explicitation in Simultaneous Interpreting: A Strategy or a By-product of Language Mediation? Across Languages and Cultures. 7(2):171-190.

Gumul, Ewa (2006b): (De)Metaforyzacja gramatyczna tekstu w tłumaczeniu symultanicznym. In: Małgorzata KiTA, ed. Żonglowanie słowami. Językowy potencjał i manifestacje tekstowe. Katowice: Wydawnictwo WSZMIJO, 161-176.

Gumul, Ewa (2008): Explicitation in Simultaneous Interpreting - The Quest for Optimal Relevance? In: Ewa WaŁaszewska, Marta Kisielewska-Krysiuk, Aniela Korzeniowska, et al., eds. Relevant Worlds: Current Perspectives on Language, Translation and Relevance Theory. Cambridge: Cambridge Scholars Publishing, 188-205.

Gumul, Ewa (2010): Explicitating Political Discourse. In: Christina Schäffner and Susan Bassnett, eds. Political Discourse, Media and Translation. Cambridge: Cambridge Scholars Publishing, 94-115.

Gumul, Ewa and ŁydA, Andrzej (2010): Disambiguating Grammatical Metaphor in Simultaneous Interpreting. In: Julian MALIszewsKI, ed. Diskurs und Terminologie beim Fachübersetzen und Dolmetschen. Discourse and Terminology in Specialist Translation and Interpreting. Frankfurt am Main: Peter Lang, 87-99.

Halliday, Michael A. K. (1985/1994): An Introduction to Functional Grammar. London/New York: Arnold.

Halliday, Michael A. K. and Hasan, Ruqaiya (1976): Cohesion in English. London/New York: Longman.

Halmari, Helena (1999): Discourse of Death: The Function of the Local Newspaper Coverage of Huntsville, Texas Executions. In: Jef Verschueren, ed. Language and Ideology. Antwerp: International Pragmatics Association, 179-205.

Hatim, Basil and Mason, Ian (1997): The Translator as Communicator. London/New York: Routledge. 
Hodge, Robert and Kress, Gunther (1993): Language as Ideology. London/New York: Routledge. JęDrzejko, Ewa (1993): Nominalizacje w systemie i w tekstach współczesnej polszczyzny. Katowice: Uniwersytet Śląski.

Kemppanen, Hannu (2004): Keywords and Ideology in Translated History Texts: A CorpusBased Analysis. Across Languages and Cultures. 5(1):89-106.

Mason, Ian (1994): Discourse, Ideology and Translation. In: Robert de Beaugrande, Abdullah Shunnaq and Mohamed Helmy Heliel, eds. Language, Discourse and Translation in the West and Middle East. Amsterdam/Philadelphia: John Benjamins, 23-34.

PIsAReK, Walery (2002): Polskie słowa sztandarowe i ich publiczność. Kraków: Universitas.

Puurtinen, Tiina (2000): Translating Linguistic Markers of Ideology. In: Andrew Chesterman, ed. Translation in Context. Amsterdam/Philadelphia: John Benjamins, 177-186.

Puurtinen, Tiina (2003): Explicitating and Implicitating Source Text Ideology. Across Languages and Cultures. 4(1):53-62.

Ravelli, Louise (1988): Grammatical metaphor: an initial analysis. In: Erich H. STEINER and Robert Veltman, eds. Pragmatics, Discourse and Text. Some Systemically-inspired Approaches. London: Pinter Publishers, 133-147.

Reah, Danuta (1998): The Language of Newspapers. London/New York: Routledge.

SChäffner, Christina (2003): Third Ways and New Centres. Ideological Unity or Difference? In: María Calzada PÉrez, ed. Apropos of Ideology. Translation Studies on Ideology - Ideologies in Translation Studies. Manchester/Northampton: St. Jerome Publishing, 23-41.

Sidiropoulou, Maria (2004): Linguistic Identities through Translation. Amsterdam/New York: Rodopi.

Simpson, Paul (1993): Language, Ideology and Point of View. London/New York: Routledge.

Sušinskiene, Solveiga (2004): Grammatical Metaphor in Scientific Discourse. Kalbotyra Slavistica Vilnensis. 54(3):xxx.

\section{APPENDIX}

\section{Texts included in the corpus}

Anderson, Bruce (8 May 2004): 'Female soldier' ought to be an oxymoron. The Spectator.

Anderson, Bruce (24 May 2004): Urodzone sadystki? Forum. 19.

Beattle, Alan, Dinmore, Gyu, Filer, Stephen, et al. (22 March 2003): Debating how to put Iraq back together again. Financial Times.

Beattle, Alan, Dinmore, Gyu, Filer, Stephen, et al. (14 April 2003): Ostatni desant tej wojny. Forum. 15.

Clover, Charles and Khalaf, Roula (5 July 2003): Iraq's campaigning consul. Financial Times.

Clover, Charles and Khalaf, Roula (14 July 2003): Namiestnik pustynny. Forum. 28.

CoRnwell, Rupert (8 March 2003): Tommy Franks: The most important soldier in a world on the edge. The Independent.

Cornwell, Rupert (17 March 2003): Najważniejszy generał świata. Forum. 11.

FIsk, Robert (27 January 2003): The Wartime Deceptions: Saddam is Hitler and it's not about oil. The Independent.

Fisk, Robert (17 February 2003): Wszystkie tuby prezydenta. Forum. 7.

FISK, Robert (26 March 2003): In the long hours of darkness, Baghdad shakes to the constant low rumble of B-52s. The Independent.

Fisk, Robert (31 March 2003): Raport z oblężonego miasta. Forum. 13.

Ghattas, Kim (31 July 2003): A New Page is Turned as Press Freedom Occupies Iraq. Financial Times.

Ghattas, Kim (11 August 2003): Bagdad drukiem kwitnący. Forum. 32.

HARI, Johann (3 December 2002): The mother of all package tours. The Guardian.

HARI, Johann (10 February 2003): Wakacje u Saddama. Forum. 6.

Kaplan, Robert (9 November 2002): A Post-Saddam Scenario. The Atlantic Monthly. 
Kaplan, Robert (6 January 2003): Inwazja - tak, ale z głową. Forum. 1.

Kellner, Peter (19 July 2003): The Voice of Baghdad. The Spectator.

Kellner, Peter (4 August 2003): Głos Bagdadu. Forum. 31.

KING, Laura (3 May 2003): With Censors Gone, Books Reemerge. Los Angeles Times.

KING, Laura (26 May 2003): Bagdad czyta. Forum. 21.

Kruger, Daniel (15 March 2003): The War Must Be Followed by Benevolent Colonialism. The Spectator.

Kruger, Daniel (31 March 2003): Kolonializm Oświecony. Forum. 13.

Lawson, Mark (19 April 2003): War games and gaffes. The Guardian.

Lawson, Mark (28 April 2003): Chłam na pamiątkę. Forum. 17.

MACASKILL, Ewen (28 October 2003): No target beyond reach as beleaguered coalition grapples with unknown enemy. The Guardian.

MaCASKIll, Ewen (3 November 2003): Nie zaznają spokoju. Forum. 44.

NYE, Joseph S. (19 May 2004): America must regain its soft power. International Herald Tribune.

Nye, Joseph S. (24 May 2004): Wojna na gesty, wojna na słowa. Forum. 21.

SACHS, Jeffrey (10 September 2003): Bush's billion will only prolong Iraq's suffering. Financial Times.

SACHS, Jeffrey (15 September 2003): Nadzieja poszła z dymem. Forum. 37.

Seaton, Matt (19 February 2003): Blast from the past. The Guardian.

Seaton, Matt (10 March 2003): Tu nic się nie powtórzy. Forum. 10.

Waller, Douglas (27 January 2003): The CIA's Secret Army. Time.

WALler, Douglas (10 February 2003): CIA zamotani w Iraku. Forum. 6.

WeIss, Stanley A. (18 April 2003): A Drama in An Najaf: Shiite Struggle is Crucial for Iraq. International Herald Tribune.

Weiss, Stanley A. (28 April 2003): Gniewne wnuki proroka. Forum. 17.

Whitworth, Damian (23 January 2003): Where's Qatar? We'll know soon. The Times.

Whitworth, Damian (3 February 2003): Wojna zacznie się od Kataru. Forum. 5.

Wise, David (27 January 2003): Why the Spooks shouldn't Run Wars. Time.

Wise, David (10 February 2003): Centralna Agencja Wojny. Forum. 6.

Wright, Robin and Williams, Daniel (13 November 2003): U.S. to Back Re-Formed Iraq Body. The Washington Post.

Wright, Robin and Williams, Daniel (17 November 2003): Dozorca pilnie poszukiwany. Forum. 46. 